\title{
Assessment of a multiplex detection method for Salmonella enterica, Escherichia coli 0157:H7, and Listeria monocytogenes in cow milk
}

\author{
Rocio Patiño Burbano ${ }^{1, *}$, Ana Karina Carrascal ${ }^{2}$, Jorge Luis Parra Arango ${ }^{3}$, \\ José Luis Rodríguez Bautista ${ }^{4}$
}

\section{Edited by \\ Juan Carlos Salcedo-Reyes \\ (salcedo.juan@javeriana.edu.co) \\ 1. Animal Health Laboratory. Tibaitatá Research Center, AGROSAVIA. \\ Mosquera, Colombia \\ 2. Food Microbiology Laboratory, \\ Environmental and Industrial \\ Biotechnology Research Group, \\ Facultad de Ciencias, Pontificia \\ Universidad Javeriana, \\ Bogotá, Colombia \\ 3. Universidad de los Llanos, \\ Villavicencio, Colombia. \\ 4. Universidade Federal Rural do Rio de Janeiro, Programa de Pós-Graduação \\ Seropédica, Brazil \\ *rpatino@corpoica.org.co}

Received: 22-11-2017

Accepted: 14-11-2018

Published on line: 06-03-2019

Citation: Patiño Burbano R,

Carrascal AK, Parra Arango JL,

Rodríguez Bautista JL. Assessment

of a multiplex detection method

for Salmonella enterica, Eschericbia coli

$\mathrm{O} 157: \mathrm{H7}$, and Listeria monocytogenes in

cow milk, Universitas Scientiarum,

24 (1): 277-294, 2019

doi: 10.11144/Javeriana.SC24-1.aoam

\section{Funding:}

Ministerio de Agricultura y Desarrollo Rural y la Corporación colombiana de investigación agropecuaria, AGROSAVIA.

Electronic supplementary material: N.A.

OPEN ACCESS

\begin{abstract}
Raw cow milk is considered one of the most important vehicles for pathogenic bacteria like Salmonella spp., Escherichia coli O157:H7, and Listeria monocytogenes. These three bacteria are responsible for foodborne diseases. Routine microbiological methods to detect these microorganisms in cow milk can be complicated and time consuming. The aim of this work was to evaluate a method to simultaneously detect Salmonella spp., Escherichia coli O157:H7, and Listeria monocytogenes in experimentally contaminated cow milk. The assessed method combined a standard microbiological culture step, using a pre-enrichment medium that favors the growth of the three focal microorganisms: SEL broth, followed by a single PCR assay. A total of 43 interference bacterial strains were used to evaluate the method's specificity. The detection rate for the microbiological method with standard culture media was $10 \mathrm{UFC} / \mathrm{mL}$, and that of the PCR detection, following pre-enrichment in SEL broth, was $10 \mathrm{UFC} / \mathrm{mL}$ for S. enterica and L. monocytogenes and between 1 and $5 \mathrm{UFC} / \mathrm{mL}$ for $E$. coli O157:H7. The PCR method showed specificity for the reference strains. Simultaneous detection by multiple PCR using SEL broth was successful for the detection of S. enterica, E. coli O157:H7, and L. monocytogenes in samples of experimentally contaminated cow milk, featuring both a high detection rate and a high specificity. This approach promises to be a feasible routine procedure when testing milk samples in industry and public health control setups.
\end{abstract}

Keywords: Foodborne diseases; food safety; hygienic quality of milk.

\section{Introduction}

The main components of cow milk are water, proteins, fat, carbohydrates, and minerals. These components exhibit quantitative variation both within and between individuals and their proportions in milk chiefly depend on cow race, feed, age, lactation period, time of the year, and milking system [1]. 
Along its production chain, cow milk quality and safety might be threatened by biological, physical, and chemical hazards. Inadequate milking and manipulation practices, lack of boiling, and insufficient cooling methods during raw milk harvesting may lead to microbial growth in a very short period, thus increasing the risk of food poisoning and foodborne infections in consumers [2].

The most important biological contaminants of raw cow milk include bacteria like Salmonella spp., Escherichia coli O157:H7, and Listeria monocytogenes [3]. These bacteria have been associated to food poisoning cases in the United States [4]. In 2014, a total of 140 food poisoning outbreaks were associated to Salmonella, 23 to Shiga toxin-producing E. coli, and 9 to L. monocytogenes; 80 out of the 140 Salmonella outbreaks were originated by consumption of food of animal origin. Among these, 15 cases were associated to the intake of unpasteurized dairy products, 3 cases due to consumption of pasteurized milk products, and 1 case involved a dairy product lacking information on hygienic protocols [4]. In Colombia, various investigations have demonstrated the presence of pathogenic microorganisms such as Brucella spp., L. monocytogenes, and Staphylococcus aureus in cow milk, and public health surveillance bodies have reported outbreaks of $E$. coli and coagulase-positive Staphylococcus associated with milk consumption [5, 6].

Commonly employed microbiological identification methods for Salmonella enterica, E. coli $\mathrm{O} 157: \mathrm{H7}$, and L. monocytogenes in milk and dairy products rely on growing samples in selective media $[7,8]$. Depending on the culture medium used, presence/absence of colonies is evaluated. Then, biochemical phenotyping and serotyping assays are performed. These culture-based microbiological detection methods take several days to identifying a given pathogen. In industry and public health surveillance setups, efficient and accurate testing methodologies are needed to ensure the timely release of consumer-safe milk and dairy products into the market. Molecular techniques are fast and efficient to detect pathogenic bacteria in food, particularly in milk. By combining both methodologies, the milk industry can have reliable test results over a short time period [7-10].

A promising molecular method for food testing is the multiplex PCR (mPCR). This method uses a group of target-specific primers to amplify different DNA fragments in a single reaction. With this technique, multiple microbial species can be simultaneously detected since the pool of primers consists of sequences targeted to a given bacterial species [11, 12]. This approach has been successfully applied to detect S. enterica, E. coli O157, and L. monocytogenes in milk [13], meat [14], cereals [15], and kimchi [16], offering the possibility to implement it as a routine technique. 
In the present study we assessed the effectiveness of the MPCR technique in detecting S. enterica, verotoxin-producing E. coli (E. coli O157:H7), and L. monocytogenes in experimentally contaminated cow milk. In parallel we conducted culture-based conventional microbiological identification tests, evaluating the use of a culture medium that favors the growth of the three focal bacteria.

\section{Materials and methods}

\section{Bacterial strains}

The bacterial strains used in this study were obtained from different reference collections. The S. enterica and L. monocytogenes reference strains were obtained from the American Type Culture Collection (strain codes ATCC13076 and ATCC19115, respectively; Microbiologics ${ }^{\circledR}$, USA) and the E. coli O157:H7 strain was obtained from the Collection of Microorganisms at Universidad Javeriana (strain code CMDM0218; Colombia). In addition, 43 bacterial strains, across 11 genera, were used to assess the MPCR assay specificity (Table 1). These microorganisms were considered because they are also common contaminants of milk $[5,6,17]$.

Culture-based approach: simultaneous detection of Salmonella enterica, Escherichia coli O157:H7 and Listeria monocytogenes with SEL broth.

For the simultaneous detection of S. enterica, E. coli O157:H7, and L. monocytogenes in cow milk, experimentally contaminated milk samples with these three microbes were cultured in SEL broth, as a pre-enrichment step, according to the method by Kim \& Bhunia [18]. Briefly, seven different microbial concentrations in a range of $10^{\circ}$ to $10^{6} \mathrm{UFC} / \mathrm{mL}$, of each microorganism, were used to experimentally contaminate $10 \mathrm{ml}$ of commercial ultra-pasteurized (UHT) milk, which was previously confirmed free of pathogens by conventional microbiological methods and PCR. Each $10 \mathrm{ml}$ contaminated milk sample was used to inoculate $90 \mathrm{~mL}$ of SEL broth. SEL broth cultures were incubated for 6 hours at $35 \pm 2{ }^{\circ} \mathrm{C}$. Later, each dilution was streaked in Hektoen agar, Mac Conkey sorbitol agar supplemented with cefixime and tellurite, and oxford agar [19-22]. All the plates were incubated at $37^{\circ} \mathrm{C}$ for 24 hours.

In parallel, the set of experimentally contaminated milk samples were evaluated for microbial contamination in three different selective culture media according to FDA and INVIMA recommendations [19-22]: Lactose pre-enriched broth was used to grow Salmonella [21], EC broth supplemented with Novobiocin (EC-N) for E. coli O157:H7, and buffered Listeria medium $\left(\right.$ Oxoid $^{\circledR}$ Thermo Fisher Scientific, USA) for Listeria. All cultures were 
Table 1. Bacterial strains used to assess multiplex PCR assay specificity. 1. Collection Universidad Javeriana; 2. Bank of Germplasm, Bacteria and Virus (Agrosavia); 3. Collection Universidad Colegio Mayor de Cundinamarca; 4. INVIMA; 5. Instituto Colombiano Agropecuario (ICA); 6. Universidad Nacional; 7. Work collection agrosavia.

\begin{tabular}{|c|c|c|}
\hline No & Bacterial strain & Source \\
\hline 1 & Bacillus cereus CD DM 019 & 1 \\
\hline 2 & Bacillus subtilis CD DM 025 & 1 \\
\hline 3 & Brucella abortus & 2 \\
\hline 4 & Escherichia coli $\mathrm{B} 001$ & 2 \\
\hline 5 & Escherichia coli ATCC 25992 & 1 \\
\hline 6 & Escherichia coli O 157:H7 CD DM 218 & 1 \\
\hline 7 & Klebsiella ascorbata CD DM 042 & 1 \\
\hline 8 & Klebsiella pneumoniae & 3 \\
\hline 9 & Klebsiella pneumoniae CD DM 041 & 1 \\
\hline 10 & Klebsiella spp. & 1 \\
\hline 11 & Listeria inocua ATCC 33090 & 4 \\
\hline 12 & Listeria ivanovii ATCC 19119 & 4 \\
\hline 13 & Listeria monocytogenes ATCC 35152 & 4 \\
\hline 14 & Listeria monocytogenes & 1 \\
\hline 15 & Listeria monocytogenes ATCC 19115 & 7 \\
\hline 16 & Listeria spp. & 7 \\
\hline 17 & Listeria spp. & 7 \\
\hline 18 & Listeria spp. & 7 \\
\hline 19 & Micrococcus luteuos CD DM 090 & 1 \\
\hline 20 & Proteus vulgaris & 3 \\
\hline 21 & Pseudomona spp. & 1 \\
\hline 22 & Pseudomona aeruginosa ATCC 27853 & 3 \\
\hline 23 & Salmonella spp. & 6 \\
\hline 24 & Salmonella spp. & 5 \\
\hline 25 & Salmonella Enteritidis & 7 \\
\hline 26 & Salmonella spp. & 1 \\
\hline 27 & Salmonella spp. & 1 \\
\hline 28 & Salmonella spp. & 1 \\
\hline 29 & Salmonella spp. & 1 \\
\hline 30 & Staphylococcus aureus & 4 \\
\hline
\end{tabular}




\begin{tabular}{|c|c|c|}
\hline 31 & Staphylococcus aureus ATCC 29213 & 3 \\
\hline 32 & Staphylococcus aureus CD DM 080 & 1 \\
\hline 33 & Staphylococcus aureus NCI MB 12702 R2 & 5 \\
\hline 34 & Staphylococcus spp. & 7 \\
\hline 35 & Staphylococcus spp. & 7 \\
\hline 36 & Streptococcus agalactiae & 3 \\
\hline 37 & Streptococcus pyogenes & 3 \\
\hline 38 & Streptococcus spp. & 6 \\
\hline 39 & Streptococcus spp. & 6 \\
\hline 40 & Streptococcus spp. & 6 \\
\hline 41 & Streptococcus spp. NCI MB 701348 R3 & 5 \\
\hline 42 & Yersinia enterocolitica ATCC 23715 & 7 \\
\hline 43 & Yersinia pseudotuberculosis ATCC 29833 & 7 \\
\hline
\end{tabular}

incubated at $35 \pm 2{ }^{\circ} \mathrm{C}$ for 24 hours. After incubation, an aliquot of each broth was streaked in selective agar broths: Hektoen agar, Mac Conkey sorbitol agar supplemented with cefixime and tellurite, and oxford agar. All the plates were incubated at $37^{\circ} \mathrm{C}$ for 24 hours.

Molecular approach: simultaneous detection of S. enterica, E. coli O157:H7 and L. monocytogenes by MPCR

The employed DNA extraction protocol followed molecular methods for microbial food contaminants [23-25]. After pre-enrichment in SEL broth, three $1 \mathrm{~mL}$ aliquots were taken from each culture; then, bacterial cells pellets were obtained with centrifugation at $4600 \mathrm{rpm}$ for 5 minutes, followed by two washes with PBS buffer (137 mM NaCl; $2.7 \mathrm{mM} \mathrm{KCl} ; 10 \mathrm{mM} \mathrm{NaH}_{2} \mathrm{PO}_{4}$; $2 \mathrm{mM} \mathrm{KH}_{2} \mathrm{PO}_{4}, \mathrm{pH} 7.4$ ) with centrifugation at $4600 \mathrm{rpm}$ for 5 minutes each. Bacterial pellets were re-suspended in $100 \mu \mathrm{L}$ Tris-EDTA lysis buffer (Tris $10 \mathrm{mM}$, EDTA $1 \mathrm{mM}, \mathrm{pH}$ 8.0; Buffer TE) plus lysozyme $(20 \mathrm{mg} / \mathrm{mL})$ and incubated at $37^{\circ} \mathrm{C}$ for 30 minutes. Then, $467 \mu \mathrm{L}$ of TE buffer, $30 \mu \mathrm{L}$ of $10 \% \mathrm{SDS}$, and $3 \mu \mathrm{L}$ of proteinase $\mathrm{K}(20 \mathrm{mg} / \mathrm{mL})$ were added to each sample and the mix was incubated at $65^{\circ} \mathrm{C}$ for 60 minutes. Next, $100 \mu \mathrm{L}$ of $\mathrm{NaCl}$ $5 \mathrm{M}$ and $80 \mu \mathrm{L}$ of Hexadecyltrimethylammonium bromide $(\mathrm{CTAB} / \mathrm{NaCl})$ were added and incubated at $65^{\circ} \mathrm{C}$ for 20 minutes. A volume of $700 \mu \mathrm{L}$ of chloroform-isoamyl alcohol (24:1) was then added to each sample. Samples 
were centrifuged at $9000 \mathrm{rpm}$ at $4{ }^{\circ} \mathrm{C}$ for 10 minutes and the resulting aqueous phase retained. A second extraction was completed adding $800 \mu \mathrm{L}$ of phenol: chloroform: isoamyl alcohol $(25: 24: 1)$ to the aqueous phase and spinning at $9000 \mathrm{rpm}$ at $4{ }^{\circ} \mathrm{C}$ for 2 minutes. Finally, DNA was precipitated with isopropanol and washed with $100 \mu \mathrm{L}$ of $70 \%$ ethylic alcohol and centrifuging at $4250 \mathrm{rpm}$ at $4{ }^{\circ} \mathrm{C}$ for 2 minutes. DNA samples were dried at room temperature and re-suspended in $50 \mu \mathrm{L}$ of buffer TE and stored refrigerated until further use.

Multiplex PCR reactions were conducted at a final volume of $25 \mu \mathrm{l}$, containing PCR Buffer 1X, MgCl2 $1.5 \mathrm{mM}$, dNTP $0.2 \mathrm{mM}$. 1.5 U of Taq Platinum $^{\circledR}$ (Invitrogen, USA), and $5 \mu$ DNA ( $100 \mathrm{ng}$ of DNA). The set of primers used in each reaction targeted highly conserved genes of $S$. enterica (gene hisJ) [26, 27], L. monocytogenes (gene blyA) [25, 28, 29], and E. coli O157:H7 (genes $v t_{1}$ and $v t_{2}$ ) [30]. Primers targeting $S$. enterica and E. coli O157:H7 genes were used at a final concentration of 5 pmol, and primers targeting the L. monocytogenes gene were used at a concentration of 40 pmol. All primer sequences are shown in Table 2.

The amplification program consisted of an initial denaturation step for 1 minute at $95^{\circ} \mathrm{C}$, followed by 30 cycles of 30 seconds at $94^{\circ} \mathrm{C}, 30$ seconds at $50.4^{\circ} \mathrm{C}$, and 1 minute at $74{ }^{\circ} \mathrm{C}$. The program was completed with one final extension step for $5 \mathrm{~min}$ at $74^{\circ} \mathrm{C}$. DNA extracted from single reference strain cultures was used as positive control in every $\mathrm{mPCR}$ reaction. All $\mathrm{mPCR}$ products were visualized in $2 \%$ agarose gels in $1 \mathrm{X}$ TAE buffer $(40 \mathrm{mM}$ Tris-acetate, $1 \mathrm{mM}$ EDTA pH $8 \pm 0.2$ ) and stained with SYBR ${ }^{\circledR}$ Safe - DNA Gel Stain (Thermo Fisher Scientific, USA). Electrophoreses were run at 90V for 90 minutes.

The sensitivity of the mPCR was assessed using DNA extracted from milk inoculated with the six concentrations of $S$. enterica, E. coli O157:H7, and L. monocytogenes. The specificity of the mPCR assay was assessed with DNA isolated from the 43 bacterial strains other than the focal bacterial trio (Table 1). These bacteria were grown in media without selective bacterial inhibitors and expanded in $\mathrm{BHI}$ broth, then $1 \mathrm{~mL}$ of each culture was used to prepare DNA with a standard phenol-chloroform protocol [24]. DNA extraction of Gram-positive bacteria was performed with lysozyme at a concentration of $2 \mathrm{mg} / \mathrm{mL}$ at $37^{\circ} \mathrm{C}$ for 30 minutes [24, 25]. Multiplex PCR amplification was performed with primers designed for the selected genes for S. enterica, E. coli O157:H7, and L. monocytogenes strains, as described in the preceding section. A sample of $10 \mathrm{~mL}$ UHT milk sample incubated in SEL broth was used as negative control. 
Table 2. Primer sequences used for the multiplex PCR (mPCR) detection of Salmonella enterica, Escherichia coli O157:H7 and Listeria monocytogenes.

\begin{tabular}{|c|c|c|c|c|c|}
\hline Bacteria & $\begin{array}{c}\text { Target } \\
\text { Gen }\end{array}$ & $\begin{array}{l}\text { Nucleotide } \\
\text { Sequence } \\
5^{\prime}-3^{\prime}\end{array}$ & $\begin{array}{l}\text { Position } \\
\text { in the gen }\end{array}$ & $\begin{array}{c}\text { Melting } \\
\text { Temperature } \\
\text { Tm }\end{array}$ & Reference \\
\hline L. monocytogenes & blyA F & caaacgttaacaacgcagta & $527-546$ & 51.2 & {$[25]$} \\
\hline L. monocytogenes & blyA R & tccagagtgatcgatgttaa & $1275-1256$ & & \\
\hline E. coli 0157:H7 & $v t_{1} \mathrm{~F}$ & gaagagtccgtgggattacg & $1191-1210$ & 55 & {$[30]$} \\
\hline E. coli 0157:H7 & $v t_{1} \mathrm{R}$ & agcgatgcagctattaataa & $1301-1320$ & & \\
\hline E. coli $0157: \mathrm{H7}$ & $v t_{2} \mathrm{~F}$ & ttaaccacacccacggcagt & $416-445$ & 59.3 & {$[30]$} \\
\hline E. coli 0157:H7 & $v t_{2} \mathrm{R}$ & gctctggatgcatctctggt & $752-771$ & & \\
\hline Salmonella spp. & bisJ F & actggcgttatccctttctctggtg & $2464516-2464540$ & 52 & This study \\
\hline Salmonella spp. & bisj $\mathrm{R}$ & atgttgtcctgcccetggtaagaga & $2465010-2464986$ & & \\
\hline
\end{tabular}

Results

Assessment of the SEL broth for the simultaneous detection of S. enterica, E. coli $\mathrm{O} 157: \mathrm{H} 7$, and L. monocytogenes

The SEL broth allowed growth of the three microorganisms in all seven concentrations evaluated. Fig. 1 depicts the growth from the concentrations $10^{4} \mathrm{UFC} / \mathrm{mL}, 10^{3} \mathrm{UFC} / \mathrm{mL}, 10^{2} \mathrm{UFC} / \mathrm{mL}$, and $10^{1} \mathrm{UFC} / \mathrm{mL}$ in differential selective agars. The detection limit for S. enterica, E. coli O157:H7 and L. monocytogenes in the SEL broth and in conventional broths was $10^{1} \mathrm{UFC} / \mathrm{mL}$ showing that this broth allows the growth of the three microorganisms. No bacterial growth was observed in any of the selective broths.

\section{Multiplex PCR sensitivity}

The mPCR assay protocol led to successful, simultaneous amplification of the fragments diagnostic of S. enterica (bisJ), E. coli O157:H7 (vt $t_{1}$ and $\left.v t_{2}\right)$ and L. monocytogenes (blyA). With this approach, we detected S. enterica and 


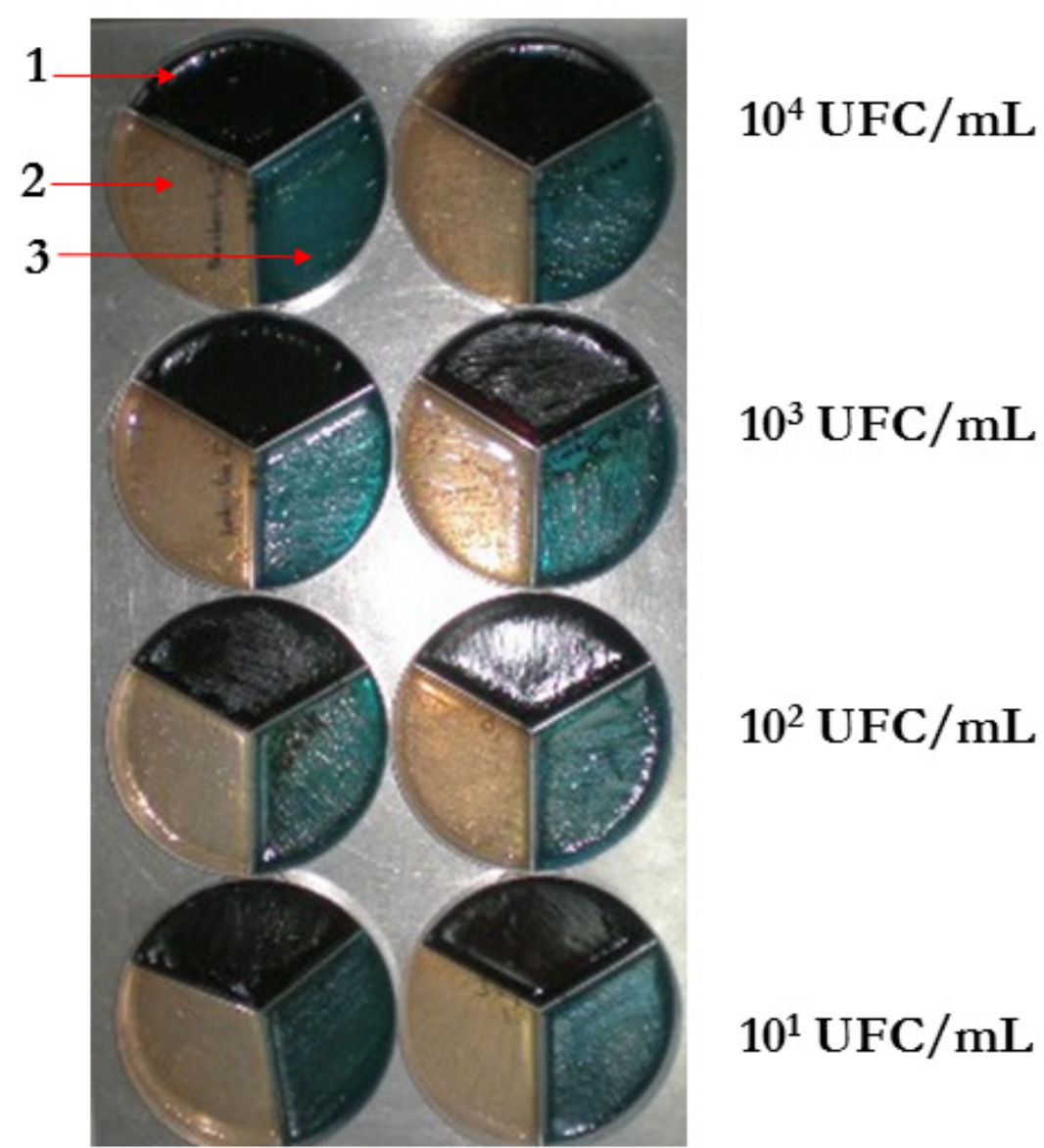

A B

Figure 1. Detection rate for the three strains in the study A: Standard method; B: SEL broth. 1: Oxford (L. monocytogenes) 2: Sorbitol-MacConkey CT media (E. coli O157:H7) and 2: Hektoen (Salmonella spp.).

L. monocytogenes from contaminated milk samples and grown in SEL broth at a concentration as low as of $10^{1} \mathrm{UFC} / \mathrm{mL}$, for each microorganism and E. coli $\mathrm{O} 157: \mathrm{H7}$ at a concentration as low as $10^{\circ} \mathrm{UFC} / \mathrm{mL}$ (Fig. 2).

\section{Multiplex PCR specificity}

Fragment amplification with this mPCR assay was strain-specific for L. monocytogenes, S. enterica, and E. coli O157:H7. No amplicons were obtained with any of the DNA material from the additional 43 bacterial strains regardless of their taxonomic proximity to those of the focal trio (Fig. 3). For instance, amplification was negative for strains of other bacterial species in the genera Listeria (Listeria inocua) and Escherichia (non-STEC E. coli). 


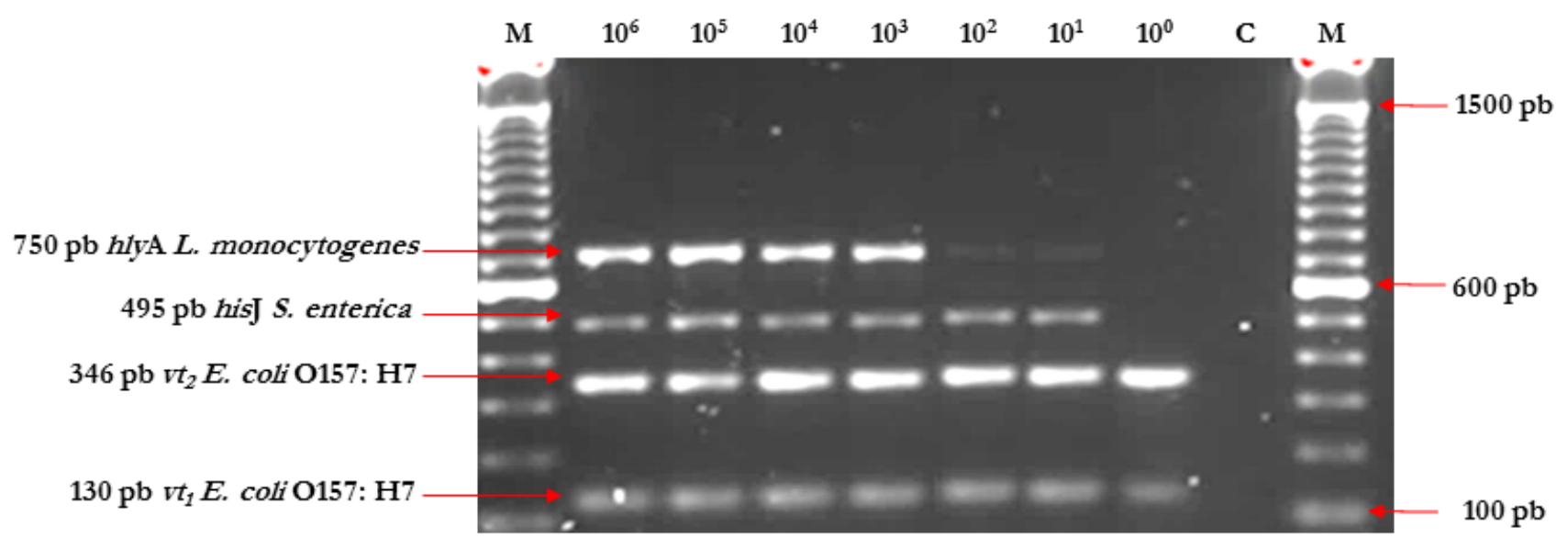

Figure 2. mPCR assay sensitivity results for $S$. enterica, E. coli O157:H7 and L. monocytogenes, using SEL broth. Lane M: Molecular size marker 100 bp (Invitrogen ${ }^{\circledR}$ ). Lanes 1 and 10, M: Molecular size marker 100 bp (Invitrogen ${ }^{\circledR}$ ); Lanes 2 to 8 correspond to PCR products from DNA material extracted from experimentally inoculated milk with pathogen concentrations: $10^{6}, 10^{5}, 10^{4}, 10^{3}, 10^{2}, 10^{1}, 10^{0} \mathrm{UFC} / \mathrm{mL}$; and Lane 9, C-: Negative control of the PCR reaction.

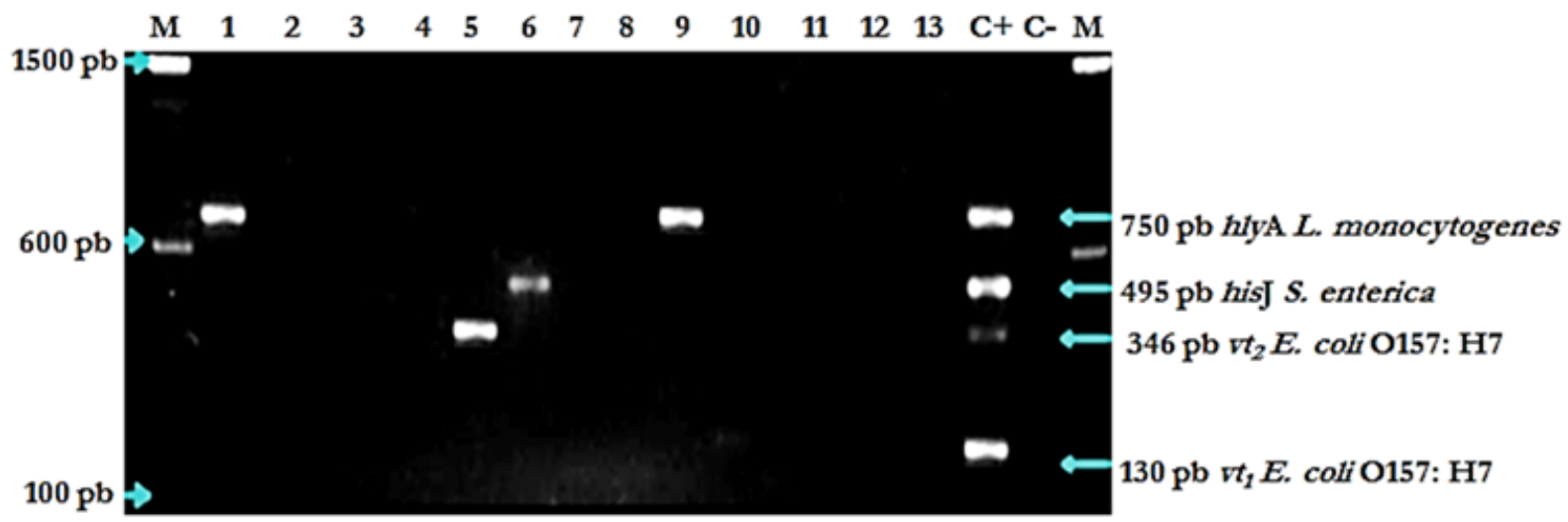

Figure 3. mPCR assay specificity evaluation results. Lanes: 1, L. monocytogenes strain 23; 2, Staphylococcus aureus CMDM080 strain 32; 3, Klebsiella ascorbata CMDM 042 strain 7; 4, Brucella abortus strain 3; 5, Escherichia coli B001 strain 4; 6, Salmonella spp. strain 23; 7, E. coli ATCC 25992 strain 5; 8, Streptococcus spp. strain 38; 9, L- monocytogenes strain 14; 10, Staphylococcus aureus strain 21; 11, Micrococcus luteus strain 19; 12, Psendomonas sp. Strain 21; 13, Streptococcus agalactiae strain 36; C+: Positive control (S. enterica, E. coli O157:H7, L. monocytogenes); C-: Negative control of the PCR reaction; M: Molecular size marker 100 bp (Invitrogen ${ }^{\circledR}$ ). 


\section{Discussion}

Milk quality and safety are compromised when contaminated with microorganisms such as S. enterica, E. coli O157:H7, and L. monocytogenes. These microorganisms are likely to be present in raw milk and dairy products due to accidental contamination during the milking process or milk handling. These microbial milk contaminants pose a threat to public health if they remain undetected along the path from primary production to the consumer. Time-efficient pathogen detection methods ought to be developed to ensure constant supply of safe foods.

In the present study we evaluated the use of pre-enriched SEL broth to simultaneously detect S. enterica, E. coli O157:H7, and L. monocytogenes in experimentally contaminated cow milk. Overall, bacterial growth in SEL broth was comparable to that achieved in strain-specific pre-enriched broths: lactose broth for S. enterica, EC-Novobiocin broth for E. coli O157:H7, and buffered Listeria broth for L. monocytogenes. Although in the present study the incubation period was shorter, our results agree with those by Kim \& Bhunia [18]. Furthermore, growth of the three microorganisms was observed across most of the range of tested inoculum concentrations, per microorganism, $\left(10^{1}\right.$ to $\left.10^{6} \mathrm{UFC} / \mathrm{mL}\right)$ after a six-hour incubation period at $37^{\circ} \mathrm{C}$. To contribute to the successful detection of several microorganisms in a single mPCR assay it was necessary to use an adequate pre-enrichment step. The universal pre-enrichment broth (UPB; DifcoLab, Sparks, MD $^{\circledR}$ ) is commercially available for multiple enrichment of pathogens; however, its lack of selectivity for certain pathogens, renders it unpractical for milk samples with high contamination levels [18]. Consequently, pre-enrichment in SEL broth culture is an efficient way to simultaneously recover the three pathogens in milk samples.

The mPCR assay appeared to be more sensitive in detecting E. coli O157:H7 than the other two focal bacterial strains at their lowest concentration level in contaminated cow milk. However, for a broad range of concentrations, $10^{1}$ to $10^{6}$ UFC, the mPCR assay's sensitivity for the three bacterial species was comparable. The mPCR assay was species-specific as revealed by the absence of amplicons when DNA of microorganisms such as Staphylococcus spp., Streptococcus spp. were used as templates. These results showed that this $\mathrm{mPCR}$ assay is a feasible technique to detect S. enterica, E. coli O157:H7, and L. monocytogenes in cow milk.

Current research aims at developing highly efficient bulk microbiological food testing methodologies favoring the use mPCR-based approaches [9, 13]. The detection of various pathogens in food via one single assay is an attractive 
and financially feasible option; it reduces laboratory resources such as space, supplies, reagents, and the work required, optimizing both total cost and running time of the tests [19-22]. The use of a molecular platform for the simultaneous detection of S. enterica, E. coli O157:H7, and L. monocytogenes, with different sensitivity degrees, has been reported for different foods. Using a Real-Time PCR approach, these three microorganisms were detected in milk after an incubation period of 18 hours at $35^{\circ} \mathrm{C}$, with a sensitivity of 1 cell $/ \mathrm{mL}$, for each microorganism $[8,28,29]$. The same technique has been applied in vegetables with a detection sensitivity of 1-10 cells $/ \mathrm{mL}$ for Salmonella and E. coli O157:H7 and 1000 cells/mL for L. monocytogenes [13]. Interestingly, in this assay the universal pre-enrichment broth (UPB) was used. This broth was formulated for the simultaneous detection of Salmonella and Listeria in food after incubation at $37^{\circ} \mathrm{C}$ for 15 hours. The mPCR approach has been used to detect the three microorganisms in other complex food matrixes. For example, in shrimp samples the detection sensitivity was $10^{3} \mathrm{UFC} / \mathrm{mL}$ for E. coli O157:H7, 100 cells for L. monocytogenes, and 1-5 cells for Salmonella, using pre-enrichment broth No. 17 incubated for $24 \mathrm{~h}$ at $35{ }^{\circ} \mathrm{C}$ [9]. In egg samples, the sensitivity was determined at 10 cells $/ 25 \mathrm{~g}$ for the three microorganisms, using tryptic soy pre-enrichment broth (TSB) after 15 hours of incubation.

PCR target genes, like specific virulence markers for E. coli O157:H7 and L. monocytogenes have been used to design simple PCR strategies for food and medical sample microbiological analysis. Two targets were chosen for E. coli $\mathrm{O} 157: \mathrm{H} 7$ falling into genes coding for two fractions of the verotoxins (Stx o Vtx). These two genes were chosen because they are highly conserved among enterohemorrhagic $E$. coli strains which, in turn, are the strains most often implicated in human toxic-infections worldwide. These two E. coli target genes have been extensively studied since 1990 and have been used in developing mPCR techniques for $E$. coli O157:H7 identification [20, 30].

The pair of primers used for the detection of $S$. enterica was designed to amplify a histidine transport protein-coding gen which is highly conserved within this genus [26-27]. The listeriolysin O-coding gene blyA (LLO) is a specific virulence factor for $L$. monocytogenes, and its amplification in PCR strategies is an excellent target for PCR-detection of $L$. monocytogenes contamination in meat and dairy products $[28,29]$.

\section{Conclusions}

The method for the simultaneous detection of S. enterica, E. coli O157:H7 and L. monocytogenes in cow milk samples, consisting of pre-enrichment in SEL medium and an MPCR assay is highly specific and sensitive. The 
specificity of the mPCR assay relied on the choice of four species-specific targets corresponding to the gene hisJ in S. enterica, genes $v t_{1}$ and $v t_{2}$ in E. coli O157:H7, and gene blyA in L. monocytogenes. The detection level of this method was $10 \mathrm{UFC} / \mathrm{mL}$ for each microorganism. Moreover, this method is likely to be both time- and cost-effective.

\section{Acknowledgements}

The authors want to thank the Ministry of Agriculture and Rural Development of Colombia (MADR) for funding this study and acknowledge AGROSAVIA for providing all the infrastructure and management support necessary to conduct the entire investigation.

\section{Conflict of interest}

The authors declare having no conflict of interests.

\section{References}

[1] Middleton J, Saeman A, Fox L, Lombard J, Hogan J, Smith K J. The National Mastitis Council: A Global Organization for Mastitis Control and Milk Quality, 50 Years and Beyond, Journal of Mammary Gland Biology and Neoplasia, 19(3-4): 241-251, 2014. doi: 10.1007/s10911-014-9328-6

[2] Claeys W, Cardoen S, Daube G, De Block J, Dewettinck K, Dierick K, De Zutter L, Huyghebaert A, Imberechts H, Thiange P, Vandenplas Y, Herman L. Raw or heated cow milk consumption: Review of risks and benefits, Food Control, 31: 251-262, 2013.

doi: 10.1016/j.foodcont.2012.09.035

[3] Centers for Disease Control and Prevention (CDC). Incidence and trends of infection with pathogens transmitted commonly through food-Foodborne Diseases Active Surveillance Network, 10 U.S. sites, 2006-2013, Morbidity and Mortality Weekly Report, 63 (15): 328-332, 2014. PMID: 23594684.

[4] Centers for Disease Control and Prevention (CDC). Vital signs: Listeria illnesses, deaths, and outbreaks--United States, 20092011. Morbidity and Mortality Weekly Report, 62(22):448-52, 2013. PMID: 23739339.

[5] Ministerio de Salud y Protección Social - Unidad de Evaluación de riesgos para la inocuidad de Alimentos (UERIA). Identificación de riesgos biológicos asociados al consumo de leche cruda bovina en Colombia, 111p. 2011. 
[6] Ministerio de Protección Social, FAO. Perfil sanitario nacional de leche cruda para consumo humano directo, 26 p. 2014.

[7] Settanni L, Corsetti A. The use of multiplex PCR to detect and differentiate food- and beverage-associated microorganisms: A review, Journal of Microbiological Methods, 69 (1): 1-22, 2007.

doi: 10.1016/j.mimet.2006.12.008

[8] Omiccioli E, Amagliani G, Brandi Giorgio, Magnani M. A new platform for Real-Time PCR detection of Salmonella spp., Listeria monocytogenes and Escherichia coli O157 in milk, Food Microbiology, 26 (6): 615-622, 2009.

doi: 10.1016/j.fm.2009.04.008

[9] Germini A, Masola A, Carnevali P, Marchelli R. Simultaneous detection of Escherichia coli O175:H7, Salmonella spp., and Listeria monocytogenes by multiplex PCR, Food Control, 20 (8): 733-738, 2009.

doi: 10.1016/j.foodcont.2008.09.010

[10] Denis E, Bielińska K, Wieczorek K, Osek J. Multiplex realtime PCRs for detection of Salmonella, Listeria monocytogenes, and verotoxigenic Escherichia coli in carcasses of slaughtered animals, Journal of Veterinary Research, 16(60): 287-292, 2016.

doi: 10.1515/jvetres-2016-0044

[11] Kawasaki S, Fratamico PM, Horikoshi N, Okada Y, Takeshita K, Sameshima T, Kawamoto S. Evaluation of a multiplex PCR system for simultaneous detection of Salmonella spp., Listeria monocytogenes, and Escherichia coli O157:H7 in foods and in food subject to freezing, Foodborne Pathogens and Disease, 6 (1): 81-89, 2009.

doi: $10.1089 /$ fpd.2008.0153

[12] Fratamico PM, Strobaugh TP. Simultaneous detection of Salmonella spp., and Escherichia coli O157:H7 by multiplex PCR, Journal of Industrial Microbiology and Biotechnology, 21 (3): 92-98, 1998.

doi: $10.1038 /$ sj.jim.2900520

[13] Aslam M, Hogan J, Smith K. Development of a PCR based assay to detect Shiga toxin-producing Escherichia coli, Listeria monocytogenes, and Salmonella in milk, Food Microbiology, 20 (3): 345350, 2003.

doi: 10.1016/S0740-0020(02)00121-1 
[14] Kawasaki S, Horikoshi, N, Okada, Y, Takeshita, K, Sameshima, T, Shinichi, K. Multiplex PCR for simultaneous detection of Salmonella spp., Listeria monocytogenes, and Escherichia coli O157:H7 in meat samples, Journal of Food Protection, 68 (3): 551-556, 2005.

doi: 10.4315/0362-028X-68.3.551

[15] Kim J, Demeke T, Clear R, Patrick S. Simultaneous detection by PCR of Escherichia coli, Listeria monocytogenes and Salmonella Typhimurium in artificially inoculated wheat grain, International Journal of Food Microbiology, 111 (1): 21-25, 2006.

doi: 10.1016/j.ijfoodmicro.2006.04.032

[16] Park Y, Lee R, Kim Y. Detection of Escherichia coli O157:H7, Salmonella spp., Staphylococcus aureus and Listeria monocytogenes in kimchi by multiplex polymerase chain reaction (mPCR), Journal of Microbiology, 44 (1): 92-97, 2006.

[17] Calderón A, Rodríguez V. Prevalencia de mastitis bovina y su etiología infecciosa en sistemas especializados en producción de leche en el altiplano cundiboyacense (Colombia), Revista Colombiana de Ciencias Pecuarias, 21: 582-589, 2008.

[18] Kim H, Bhunia A. SEL, a selective enrichment broth for simultaneous growth of Salmonella enterica, Escherichia coli O157:H7, and Listeria monocytogenes, Applied and Environmental Microbiology, 74 (15): 4853-4866, 2008.

doi: 10.1128/AEM.02756-07

[19] INVIMA. Manual of techniques to analyze microbiological quality control of food for human consumption, 111 p, 1998.

doi: $10.1089 /$ fpd.2008.0153

[20] Feng P, Weagant SD, Jinneman K. Diarrheagenic Escherichia coli, Bacteriological Analytical Manual Chapter 4A. Maryland, USA: US Food and drug administration, 2016.

Retrieved from:

http: / / www.fda.gov/Food / FoodScienceResearch / LaboratoryMethods/ucm070080.htm

[21] Andrews W, Hammack T. Salmonella. Bacteriological Analytical Manual, Chapter 5 Maryland, USA: US Food and drug administration, 2016.

Retrieved from:

http: / / www.fda.gov/Food / FoodScienceResearch / LaboratoryMethods/ucm2006949.htm 
[22] Hitchins AD, Jinneman K. Detection and enumeration of Listeria monocytogenes in foods, Bacteriological Analytical Manual Chapter 10, Maryland, USA: US Food and drug administration, 2016.

Retrieved from:

http: / / www.fda.gov/Food / FoodScienceResearch / LaboratoryMethods/ucm071400.htm

[23] Wilson K. Preparation of Genomic DNA from Bacteria, Current Protocols in Molecular Biology, 56(1): 2.4.1-25B.4.17, 2001.

doi: 10.1002/0471142727.mb0204s56

[24] Asadzadeh N, Javanmard A, Nassiry M. Comparison of rapid DNA extraction techniques for conventional PCR-RFLP analysis from mammalian whole blood cells, Journal of Molecular Genetics, 2 (3-4): 32-35, 2010.

doi: 10.3923/jmolgene.2010.32.35

[25] Poutou R. Burbano M, Sierra S. Torres K. Carrascal AK, Mercado M. Estandarización de la extracción de ADN y validación de la PCR múltiple para detectar Listeria monocytogenes en queso, leche, carne de res y pollo, Universitas Scientiarum, 10 (2): 61-78, 2005.

[26] Ames G, Noel K, Taber H, Spudich E, Nikaido K, Afong J. Fine-structure map of the histidine transport genes in Salmonella typhimurium, Journal of Bacteriology, 129(3):1289-1297. 1977. PMID: 321422.

[27] Freschi CR, Silva Carvalho LF; Oliveira CJ. Comparison of DNA-extraction methods and selective enrichment broths on the detection of Salmonella Typhimuriumin swine feces by Polymerase Chain Reaction (PCR), Brazilian Journal of Microbiology, 36 (4): 363-367, 2005.

doi: 10.1590/S1517-83822005000400011

[28] Burbano E, Sierra S, Torres K, Mercado M, Carrascal A, Poutou R. Rapid DNA extraction and PCR validation for direct detection of Listeria monocytogenes in raw milk, Revista MVZ Córdoba, 11(1): 715-724, 2006.

doi: $10.21897 /$ rmvz.456

[29] Vanegas MC, Vásquez E, Martínez AJ, Rueda AM. Detection of Listeria monocytogenes in raw whole milk for human consumption in Colombia by real-time PCR, Food Control, 20(4): 430-432, 2009. doi: 10.1016/j.foodcont.2008.07.007 
[30] Pollard DR, Johnson WM, Lior H, Tyler D, Rozee KR. Rapid and specific detection of verotoxin genes in Escherichia coli by the polymerase chain reaction, Journal of Clinical Microbiology, 28(3); 540-545, 1990. PMCID: PMC26965.

\section{Determinación de un método de detección múltiple para Salmonella enterica, Escherichia coli 0157:H7 y Listeria monocytogenes en leche de vaca}

Resumen: La leche cruda de vaca se considera uno de los vehículos más importantes de bacterias patógenas como Salmonella spp., Escherichia coli O157:H7 y Listeria monocytogenes. Estas tres bacterias son responsables de enfermedades transmitidas por alimentos. Los métodos microbiológicos de rutina para detectar estos microorganismos en leche cruda de vaca pueden ser complicados y requerir mucho tiempo. El objetivo de este trabajo fue evaluar un método para detectar simultáneamente Salmonella spp., Escherichia coli O157:H7 y Listeria monocytogenes en leche de vaca contaminada experimentalmente. El método utilizado combinó una etapa de pre-enriquecimiento con cultivo microbiológico estándar utilizando un medio que favorece el crecimiento de los tres microrganismos focales (caldo SEL) seguido de un único ensayo de PCR. Se utilizaron 43 cepas de microorganismos de interferencia para evaluar la especificidad del método. La tasa de detección para el método de cultivo microbiológico estándar fue de $10 \mathrm{UFC} / \mathrm{mL}$, y la de detección por PCR, después de pre-enriquecimiento en caldo SEL, fue de $10 \mathrm{UFC} / \mathrm{mL}$ para $S$. enterica y L. monocytogenes y entre 1 y $5 \mathrm{UFC} /$ mL para E. coli O157:H7. El método PCR mostró especificidad para las cepas de referencia. La detección simultánea por PCR múltiple, luego de pre-enriquecimiento en caldo SEL fue exitosa para la detección de S. enterica, E. coli O157:H7 y L. monocytogenes en muestras de leche de vaca contaminada experimentalmente, mostrando tanto una alta tasa de detección como una alta especificidad. Esta aproximación promete ser un procedimiento de rutina factible cuando se analizan muestras de leche en la industria y en actividades de control de salud pública.

Palabras clave: enfermedades transmitidas por alimentos; inocuidad de los alimentos; calidad higiénica de la leche. 


\section{Determinação de um método de detecção múltipla para Salmonella enterica, Escherichia coli O157:H7 e Listeria monocytogenes em leite de vaca}

Resumo: O leite de vaca cru é considerado um dos mais importantes veículos para bactéricas patogênicas como Salmonella spp., Escherichia coli O157:H7 e Listeria monocytogenes. Estas três bactérias são responsáveis por enfermidades transmitidas por alimentos. Os métodos microbiológicos de rotina para detectar estes micro-organismos em leite de vaca cru podem ser complicados e demandantes de tempo. O objetivo de este trabalho foi avaliar um método para detectar simultaneamente Salmonella spp., Escherichia coliO157:H7 e Listeria monocytogenes em leite de vaca contaminado experimentalmente. O método utilizado combinou uma etapa de préenriquecimento com cultura microbiológica padrão utilizando um meio que favorece o crescimento dos três micro-organismos focais (caldo SEL). Utilizaram-se 43 cepas de micro-organismos de interferência para avaliar a especificidade do método. A taxa de detecção para o método de cultura microbiológica padrão foi de $10 \mathrm{UFC} / \mathrm{mL}$, e a de detecção por PCR, posteriormente ao pré-enriquecimento em caldo SEL, foi de $10 \mathrm{UFC} / \mathrm{mL}$ para $S$. enterica e $L$. monocytogenes e entre 1 e $5 \mathrm{UFC} / \mathrm{mL}$ para E. coli O157:H7. O método por PCR mostrou especificidade para as cepas de referência. A detecção simultânea por PCR múltiplex, logo do pré-enriquecimento em caldo SEL, foi exitosa para a detecção de $S$. entérica, E. coli O157:H7 e L. monocytogenes em amostras de leite de vaca contaminado experimentalmente, demostrando tanto uma alta taxa de detecção como uma alta especificidade. Esta aproximação promete ser um procedimento de rotina viável quando se analisam amostras de leite na indústria e nas atividades de controle de saúde pública.

Palavras-chave: enfermidades transmitidas por alimentos; inocuidade dos alimentos; qualidade higiênica do leite. 


\section{Rocio Esperanza Patiño Burbano}

Rocio's research interests focus in the isolation and phenotypic-genotypic characterization of pathogenic microorganisms that affect animal and public health. Her research projects address the need to constantly develop and evolve ways to ensure the quality and safety of dairy, beef, and bee products, framed within Animal Health, Food Safety, and Animal Welfare topics. Her research experience has been strongly associated to the validation of diagnostic methods for animal diseases.

ORCID: 0000-0003-2970-9876

\section{Ana Karina Carrascal Camacho}

Ana Karina's main research interest is directed to food safety and emerging foodborne diseases, especially due to microbiological hazards such as Listeria monocytogenes. Ana Karina's current research aims at identifying the sources or microbial food contamination and at designing strategies for microbial hazard control of food at the industry level.

ORCID: 0000-0002-5826-4530

\section{Jorge Luis Parra Arango}

Jorge Luis research focuses on animal health and production systems. In particular, he studies microbial-associated gestational loss, morbidity, and mortality in calves, lambs, piglets, and juveniles of several animal species. In addition, Jorge Luis has worked in research projects related to the quality and safety of animal products, by-products as well as waste and contaminants in bovine production systems.

ORCID: 0000-0002-5270-4259

\section{José Luis Rodríguez Bautista}

Jose's research focuses on identifying the baseline of milk quality parameters and their association to management practices and farm structure. Jose works on determining the risk of contamination by pathogenic bacteria and chemical residues in products of the dairy cattle value chain in order to contribute to milk quality improvement and to reduce the risk of food poisoning, and associated health issues, among consumers.

ORCID: 0000-0002-9407-171X 